J. Dairy Sci. 98:5709-5719

http://dx.doi.org/10.3168/jds.2014-9163

(C) American Dairy Science Association ${ }^{\circledR}, 2015$.

\title{
Feeding fat from distillers dried grains with solubles to dairy heifers: II. Effects on metabolic profile
}

\author{
J. L. Anderson, ${ }^{* 1}$ K. F. Kalscheur, ${ }^{* 2}$ J. A. Clapper, † G. A. Perry, † D. H. Keisler, $\ddagger$ A. D. Garcia, ${ }^{*}$ \\ and D. J. Schingoethe* \\ *Dairy Science Department, and \\ †Department of Animal Science, South Dakota State University, Brookings 57007 \\ ‡Division of Animal Sciences, University of Missouri, Columbia 65211
}

\section{ABSTRACT}

The objective of this study was to determine if increased dietary fat from dried distillers grains with solubles (DDGS) in diets of growing heifers affected metabolic profile, plasma fatty acid profile, and reproductive maturation. Thirty-three Holstein heifers $(133 \pm 18 \mathrm{~d}$ of age $)$ were used in a 24 -wk randomized complete block design with 3 treatment diets. Treatment diets were (1) control (CON) containing ground corn $(15.9 \%$ of DM) and soybean products (17.9\%), (2) low-fat (LFDG) containing low-fat DDGS (21.9\%) and ground corn (11.9\%), or (3) high-fat (HFDG) with traditional DDGS (33.8\%). Diets were isonitrogenous and isocaloric, but the HFDG diet was formulated to contain $4.8 \%$ fat compared with $2.8 \%$ in the CON and LFDG diets. All 3 diets were limit-fed to $2.45 \%$ of body weight on a dry matter basis, and resulted in a mean average daily gain of $0.96 \mathrm{~kg} / \mathrm{d}$ across treatments. Every $4 \mathrm{wk}$, jugular blood was collected for analysis of metabolites and metabolic hormones. During wk 20 of the feeding period, blood samples were collected for analysis of plasma fatty acid profiles. When heifers weighed between 200 and $300 \mathrm{~kg}$ of body weight, coccygeal blood samples were taken twice weekly for analysis of progesterone to determine if puberty had been reached. Plasma concentrations of nonesterified fatty acids were similar among treatments and consistent over the duration of the study. Plasma concentrations of $\beta$-hydroxybutyrate, insulin, insulin-like growth factor-1, and leptin were similar among heifers fed each treatment diet, but increased over the duration of the feeding period. Serum concentrations of glucose tended to be less in heifers fed HFDG compared with heifers

\footnotetext{
Received November 26, 2014.

Accepted April 28, 2015.

${ }^{1}$ Corresponding author: jill.anderson@sdstate.edu

${ }^{2}$ Current address: US Dairy Forage Research Center, USDA-ARS, 1925 Linden Drive West, Madison, WI 53706.
}

fed the CON diet. Glucose concentrations fluctuated throughout the feeding period, but no treatment by time interactions were noted. Plasma urea $\mathrm{N}$ concentrations were less in heifers fed LFDG compared with heifers fed HFDG and CON diets. The concentrations of plasma urea $\mathrm{N}$ increased over the duration of the feeding period, with no treatment by week interaction. Total plasma cholesterol was greater in heifers fed HFDG compared with the CON and LFDG diets, and a significant week effect and a week by treatment interaction were observed. Fatty acid profiles also differed among treatments based on the supply of fatty acids from the diet. Progesterone analysis indicated that heifers fed HFDG tended to be pubertal at a younger age than heifers on CON. These results demonstrate that dietary fat from DDGS can be used in high-plane of nutrition rations for growing heifers and maintain metabolic energy status compared with starch from corn, but alters the concentrations of different blood lipids.

Key words: dairy heifer, distillers grains, metabolic profile

\section{INTRODUCTION}

Previous research on feeding distillers grains to dairy heifers has demonstrated that growth performance can be maintained compared with feeding other common feedstuffs (Anderson et al., 2009; Schroer et al., 2014). It has been established in previous research (Anderson et al., 2006, 2009; Schingoethe et al., 2009) that feeding conventional distillers grains at increasing inclusion rates also increases dietary fat concentrations. Because of these changes in dietary nutrient profile compared with traditional corn- and soybean-based diets, metabolites, metabolic hormones, and body composition may be affected. It was speculated that metabolic changes may be occurring despite similar ADG or skeletal growth, even when all heifers are fed on a high plane of nutrition. Changes in metabolic profile are of particular interest in dairy heifers for several reasons. First, 
metabolic status and body composition are linked to the onset of puberty (Funston et al., 2012; Perry, 2012). Second, timing of puberty and rate of gain have been found, in turn, to influence mammary development and subsequent milk production (Tucker, 1981; Van Amburgh et al., 1998; Zanton and Heinrichs, 2005). In light of these findings, determining if increased dietary fat from feeding distillers dried grains with solubles (DDGS) results in changes in metabolic profile, in particular, metabolites and hormone related to energy metabolism, or onset of puberty is an important endeavor because differences could influence long-term performance.

Research regarding effects of feeding specific FA profiles to growing dairy calves and heifer diets is lacking. It is speculated that certain FA may be more beneficial than others, although results were conflicting in calf study by Hill et al. (2009) and a calf-to-heifer (0-6 mo of age) feeding study by Thibault et al. (2003). Polyunsaturated fat was reported to increase pubertal mammary growth in sheep (McFadden et al., 1990), but Thibault et al. (2003) fed dairy heifers a high-soybean oil diet that was high in linoleic acid and found no differences in growth or mammary development. Ambrose et al. (2006) demonstrated that dietary supplementation of PUFA, in particular $\alpha$-linolenic acid, improved reproduction in lactating cows, and Thomas et al. (1997) demonstrated that isolipidic diets affected reproduction differently depending on degree of saturation in beef heifers.

Leptin is of interest because it may be a link between metabolic status and reproductive status (Zieba et al., 2005). When growing animals reach a certain metabolic status or body fat composition, leptin is thought to have a permissive action on release of gonadotropin releasing hormone (Zieba et al., 2004, 2005). In beef heifers it has been demonstrated that serum concentrations of leptin increased in a linear fashion from 16 wk before puberty until the week of ovulation (Maciel et al., 2004).

Distillers dried grains with solubles have a relatively high fat value at 10 to $15 \%$ ether extract. Typically $50 \%$ of the fat in DDGS is linoleic acid (C18:2; Leonardi et al., 2005; Anderson et al., 2006, 2009). Linoleic acid is thought to be one of the essential FA because it can be elongated to arachidonic acid and cholesterol, which are used for hormone synthesis and cellular membranes (Simopoulos, 1991). In beef heifers, research revealed that feeding DDGS did not affect age or BW at puberty, but did improve AI conception rates and pregnancy rates compared with a control supplement of equal energy (Martin et al., 2007).

The major objective of our study was to characterize how increased dietary fat from feeding a high inclu- sion rate of DDGS affected the blood metabolic profile, including key metabolic hormones and metabolites related to energy metabolism, in growing dairy heifers fed on a high plane of nutrition. Because FA composition has been shown to differentially affect reproduction, it was also a goal to characterize the plasma FA profiles. A secondary objective was to determine if changes in metabolism were enough to change age at onset of puberty. However, because of the scope of this research we were only able to use low numbers of heifers, thus the secondary objective was preliminary in nature and focused more on determining if future research is warranted rather than making definitive conclusions. The main hypothesis was that metabolic and FA profiles would be different between the HFDG diet compared with the CON and LFDG diets because of the replacement of starch with fat as an energy source in diets that provided for high rates of ADG. It was also hypothesized that changes in metabolic profiles may influence the age at onset of puberty among treatments.

\section{MATERIALS AND METHODS}

\section{Experimental Design}

Samples for this research were taken during the feeding study described in the companion paper (Anderson et al., 2015); for more details on diets, feeding protocols, and heifer growth characteristics, refer to that paper. Briefly, 33 heifers were used in randomized complete block design with 3 dietary treatments. The study lasted for 24 wk during the prepubertal growth period. The 3 treatment diets (Table 1) were a control diet containing corn and soybean products $(\mathbf{C O N})$, a diet utilizing low-fat distillers dried grains that was similar to the control in starch and fat content (LFDG), and a diet containing traditional DDGS that was lesser in starch and higher in fat (HFDG) compared with the CON and LFDG diets. All diets contained approximately $40 \%$ grass hay and $25 \%$ corn silage on a DM basis. The diets were formulated to be isonitrogenous and isocaloric. Diets were limit-fed to $2.45 \%$ of BW on a DM basis. Diets provided for a high plane of nutrition, as ADG averaged $0.96 \mathrm{~kg} / \mathrm{d}$ for the 3 treatments (Anderson et al., 2015). Throughout the feeding period, collection of blood samples was performed for assessment of metabolic and reproductive status of the growing heifers via analysis of hormones and metabolites.

\section{Sample Collection and Analysis}

For analysis of glucose, NEFA, BHBA, cholesterol, plasma urea nitrogen (PUN), insulin, IGF-1, and 
Table 1. Ingredients and nutrient composition of the control diet $(\mathrm{CON})$, the low-fat diet containing fat extracted dried distillers grains with solubles (LFDG), and the high-fat diet containing traditional dried distillers grains with solubles (HFDG) fed to growing Holstein heifers

\begin{tabular}{lccc}
\hline & & Diet & \\
\cline { 2 - 4 } Item $^{1}$ & CON & LFDG & HFDG \\
\hline Ingredient, \% of DM & & & \\
Grass hay & 39.79 & 39.78 & 39.79 \\
Corn silage & 24.86 & 24.86 & 24.85 \\
Dried distillers grains with solubles (DDGS) & 0 & 0 & 33.80 \\
Low-fat DDGS & 0 & 21.88 & 0 \\
Ground corn & 15.91 & 11.93 & 0 \\
Soybean meal, 44\% CP & 8.95 & 0 & 0 \\
Expellers soybean meal ${ }^{2}$ & 8.95 & 0 & 0 \\
Limestone & 0.40 & 0.40 & 0.40 \\
Mineral premix ${ }^{3}$ & 0.78 & 0.78 & 0.80 \\
Salt & 0.36 & 0.36 & 0.36 \\
Nutrient, \% of DM (unless otherwise noted) & & 71.8 & 70.7 \\
DM,\% of diet & 71.0 & 16.3 & 16.7 \\
CP & 15.8 & 3.08 & 7.00 \\
Ether extract (diethyl) & 2.91 & 2.22 & 4.72 \\
Oil & 1.97 & 19.0 & 8.3 \\
Starch & 20.4 & 2.45 & 2.46 \\
ME, Mcal/kg of DM & 2.48 & 0.96 & 0.96 \\
NE ${ }_{G}$, Mcal/kg of DM & 0.97 & & \\
\hline
\end{tabular}

${ }^{1}$ Diets were formulated to meet or exceed requirements with NRC (2001). Nutrient composition based on analysis described by Anderson et al. (2015).

${ }^{2}$ SoyPlus (West Central Cooperative, Ralston, IA).

${ }^{3}$ Contained: $2.2 \mathrm{~g} / \mathrm{kg}$ of lasolocid sodium, $16.05 \% \mathrm{Ca}, 10.0 \% \mathrm{P}, 20.45 \% \mathrm{NaCl}, 2.0 \% \mathrm{Mg}, 0.7 \% \mathrm{~K}, 0.8 \% \mathrm{~S}, 5,520$ $\mathrm{mg} / \mathrm{kg}$ of Zn, 3,700 mg/kg of Mn, $1,000 \mathrm{mg} / \mathrm{kg}$ of Fe, $1,010 \mathrm{mg} / \mathrm{kg}$ of Cu, $86 \mathrm{mg} / \mathrm{kg}$ of I, $25 \mathrm{mg} / \mathrm{kg}$ of Co, 53 $\mathrm{mg} / \mathrm{kg}$ of Se, 704,000 IU/ $\mathrm{kg}$ of vitamin A, 140,800 IU/ $\mathrm{kg}$ of vitamin $\mathrm{D}_{3}$, and 5,280 IU $/ \mathrm{kg}$ of vitamin E (Future Cow Supreme Premix B2000, Land O' Lakes, Inc., St. Paul, MN).

${ }^{4}$ Heifers were provided ad libitum access to white salt $(\mathrm{NaCl})$ blocks, which are not accounted for in these values.

leptin blood samples were taken at the beginning of the study and then every 2 wk throughout on 2 consecutive days. Blood samples were taken approximately $3.5 \mathrm{~h}$ postfeeding $(1230 \mathrm{~h})$ via venipuncture of the jugular vein into Vacutainer tubes (Becton, Dickinson, and Company, Franklin Lakes, NJ) containing NaFl for glucose analysis or $\mathrm{K}_{2}$ EDTA for all other analyses. Following blood collection, samples were immediately placed on ice and then brought within $3 \mathrm{~h}$ to the laboratory for processing. Blood collection tubes were centrifuged at $1,000 \times g$ for $20 \mathrm{~min}$ at $4^{\circ} \mathrm{C}(\mathrm{CR} 412$ Jouan Inc., Winchester, VA). Plasma (from the $\mathrm{K}_{2}$ EDTA tubes) or serum (from the $\mathrm{NaFl}$ tubes) was then transferred into polystyrene storage tubes and frozen at $-20^{\circ} \mathrm{C}$ until further processing and analysis could be completed. Before analysis, the samples from the 2 consecutive days from each week were composited together by volume and aliquots were obtained for each respective assay. Based on the consistency of growth data among treatments (Anderson et al., 2015) it was decided to assay only samples from wk $0,4,8,12,16,20$, and 24 of the feeding period, with samples for the other weeks kept as back-up samples.
Metabolites (glucose, NEFA, BHBA, cholesterol, and PUN) were analyzed with commercially available enzymatic or colorimetric assay kits on a microplate spectrophotometer (Cary 50, Varian Inc., Walnut Creek, CA.) Serum glucose was analyzed using glucose oxidase as described by Trinder (1969; Pointe Scientific Inc., Canton, MI). Nonesterified fatty acids were analyzed using methods described by Johnson and Peters (1993; NEFA C kit; Wako Chemicals Inc., Richmond, VA). Beta-hydroxybutyrate dehydrogenase and diaphorase were used for analysis of plasma BHBA as described by Williamson et al. (1962; Pointe Scientific Inc.). Plasma total cholesterol was analyzed using cholesterol esterase and oxidase (Pointe Scientific Inc.) as described by Allain et al. (1974). Plasma urea nitrogen was analyzed using diacteyl monoxime (Procedure 0580; Stanbio Laboratory, Boerne, TX).

For metabolic hormones, including insulin, IGF-1, and leptin, plasma samples were analyzed by RIA. Insulin was quantified by solid-phase RIA (Coat-ACount, Diagnostic Products Corp., Los Angeles, CA) within a single assay with an interassay coefficient of variation of $3.9 \%$. Plasma concentrations of IGF-I were 
determined in duplicate by RIA as described by Echternkamp et al. (1990) and Funston et al. (1995). To extract the insulin-like growth factor binding proteins (IGF-BP) from the plasma, samples were incubated overnight with a ratio of 1:17 sample to acidified ethanol (12.5\% $2 \mathrm{~N} \mathrm{HCl:87.5 \%}$ absolute ethanol; Daughaday et al., 1980). To separate the extracted IGF-BP, the samples were then centrifuged $\left(12,000 \times g\right.$ at $4^{\circ} \mathrm{C}$ for $10 \mathrm{~min})$. An aliquot of supernatant was removed and neutralized with $0.855 M$ Tris base. Samples were then incubated overnight again at $4^{\circ} \mathrm{C}$ and, to remove any residual, IGF-BP samples were again centrifuged $\left(12,000 \times g\right.$ at $4^{\circ} \mathrm{C}$ for $\left.10 \mathrm{~min}\right)$. Inhibition curves of the neutralized extracted plasma (range 25-50 $\mu \mathrm{L}$ ) were determined. The radioiodinated antigen and standard used was recombinant human IGF-I (GF-050; Austral Biological, San Ramon, CA). At a dilution of 1:50,000, Antisera AFP4892898 (National Hormone and Peptide Program, Harbor-UCLA Medical Center, Torrance, CA) was used. Assay sensitivity was $15.23 \mathrm{pg} /$ tube. Samples were analyzed within 1 assay and intra-assay coefficient of variation was $8.22 \%$. Samples for leptin analysis were sent to the University of Missouri for analysis by a highly sensitive ovine leptin RIA, which was validated for bovine plasma (Delavaud et al., 2007). All samples were analyzed within 1 assay and interassay coefficient of variation was $8.15 \%$.

During wk 20, extra blood was taken and plasma was harvested, as previously described, for FA determination. Plasma lipid extractions were performed as described by Bligh and Dyer (1959). Extracted lipids were then prepared for FA analysis using butylation methods, as described by Sukhija and Palmquist (1988) with adaptations by Abdelqader et al. (2009). Feed samples for FA analysis were collected and processed as described in Anderson et al. (2015). Four-month feed composites were analyzed for FA profiles via direct butylation techniques (Abdelqader et al., 2009). All prepared FA samples were analyzed via GC (Hewlett Packard 6890, Palo Alto, CA) as described by Abdelqader et al.(2009).

To test for precocious onset of puberty, additional blood samples were taken for progesterone analysis. Sampling began when each heifer reached $200 \mathrm{~kg}$ of BW and continued until they reached $300 \mathrm{~kg}$ of BW. Blood samples were taken via coccygeal venipuncture into Vacutainer tubes (Becton Dickinson Co.) containing $\mathrm{K}_{2}$ EDTA twice weekly (Tuesday and Friday). Plasma was harvested as previously described. Plasma progesterone concentrations were determined using a validated RIA procedure as described by Engel et al. (2008). Inter- and intra-assay coefficients of variation were 2.94 and $11.3 \%$, respectively, and assay sensitiv- ity was $0.4 \mathrm{ng} / \mathrm{mL}$. Precycling baseline progesterone concentrations averaged $0.42 \pm 0.182 \mathrm{ng} / \mathrm{mL}$ among treatments. Heifers were determined to have reached puberty when progesterone concentrations were greater than $1 \mathrm{ng} / \mathrm{mL}$, indicating that corpus lutea had formed and that estrous cycling and ovulation had begun.

\section{Calculations and Statistical Analyses}

All statistical analyses were conducted using SAS 9.3 (SAS Institute Inc., Cary, NC). For feed FA analysis, data were compiled and standard errors were calculated using the MEANS procedure in SAS. Dietary FA values were calculated based on analysis of the concentrate mixes, corn silage, and hay for each treatment over the course of the study. For plasma FA, analysis was conducted with the MIXED procedure in SAS. The model included treatment with the block as a random variable. Least squares means for each treatment are reported in the tables and were compared using Tukey's test. Plasma metabolites and metabolic hormones data were analyzed with the inclusion of week as the repeated measure using MIXED procedures (Littell et al., 2008). Main effects in the model were treatment, week, and treatment $\times$ week interactions. Values for initial measurement were found to be different among treatments, thus they were accounted for within the model as a covariate term. For the repeated measures, Akaike's criteria were used for each parameter to determine the most suitable covariance structure. Least squares means for each treatment are reported in the tables and were compared among treatments using Tukey's test. Puberty data were analyzed as binomial data (cycling or noncycling) by certain criteria for age or weight. Also, puberty was analyzed using repeated measures by 10-d intervals of age. Significant differences among treatments for all analysis were declared at $P<0.05$ and tendencies for treatment differences were declared at $0.05<P<0.10$.

\section{RESULTS}

$F A$

Table 2 shows the FA profiles for the overall diets. These results agree with ether extract values in Table 1 and show that the HFDG diet had more fat compared with the CON and LFDG diets. More total FA, C16:0, C16:1, C18:1 cis-9, and C18:2 as dietary concentrations $(\mathrm{g} / \mathrm{kg}$ of DM) were observed in the HFDG compared with the LFDG and CON.

Plasma FA are presented as the profile of total FA $(\mathrm{g} / 100 \mathrm{~g}$ of $\mathrm{FA})$ and as plasma concentration $(\mu \mathrm{g} /$ 
Table 2. Fatty acid compositions of the control diet (CON), the low-fat diet containing fat-extracted dried distillers grains (LFDG), and the high-fat diet containing traditional dried distillers grains with solubles (HFDG)

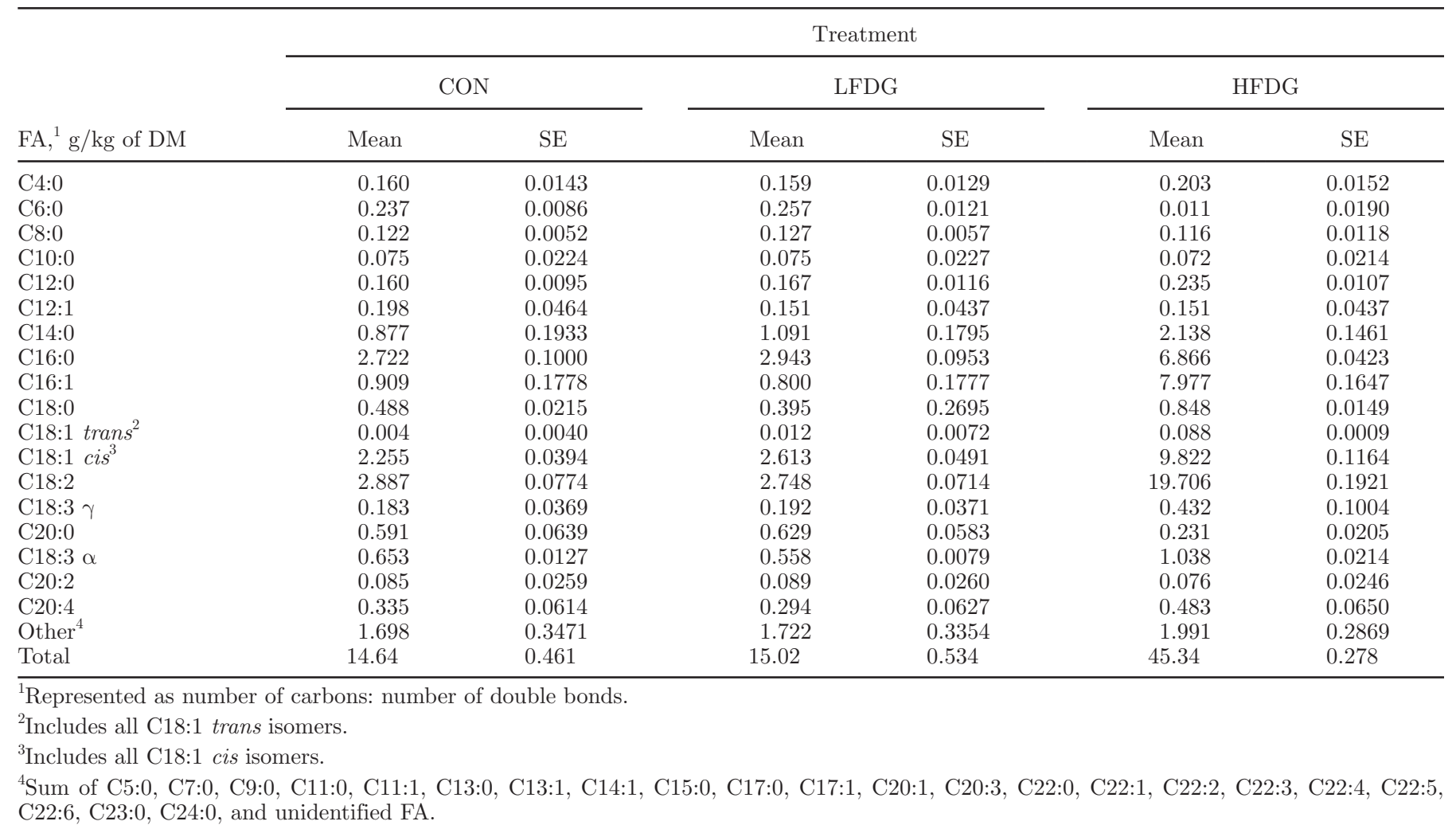

$\mathrm{mL}$ of plasma) in Table 3. Overall when comparing the profile of FA, only a few major differences were noted among treatments. When examining FA profiles, linoleic acid (C18:2) was the largest proportion of FA in all 3 treatments. Comparing the FA profiles among treatments, heifers fed the HFDG had greater $(P<$ 0.05) proportion of C18:2 compared with the CON-fed heifers. Palmitic (C16:0) and stearic acid (C18:0) were similar proportions of the FA profiles in all 3 treatments. When comparing to FA profiles to total concentration of FA in the plasma, differences were observed in what was statistically different among treatments. Plasma from heifers fed the HFDG had similar plasma concentrations of C18:2 compared with the heifers fed the LFDG diet, but greater concentrations compared with the CON diet. Plasma concentrations of C16:0 and C18:0 were greatest in heifers fed HFDG. Heifers fed the HFDG diet also had greater $(P<0.05)$ plasma concentrations of C18:1 trans- 9 and $\mathrm{C} 20: 4$ compared with the CON-fed heifers. The heifers fed the CON diet had greater plasma FA concentration of C18:1 cis-9 compared with the LFDG and HFDG-fed heifers. Heifers fed the HFDG diet had greater $(P<0.05)$ plasma concentration of total FA compared with the heifers fed the CON diet, but were similar to heifers fed the LFDG diet.

\section{Metabolites and Metabolic Hormones}

Metabolites and metabolic hormone concentrations are presented in Table 4 . Heifers fed the CON diet had greater glucose concentrations compared with heifers fed the HFDG diet. However, the LFDG diet was not statistically different from either treatment. Plasma NEFA concentrations were not different among treatments, with no treatment or treatment by time interaction. Plasma BHBA concentrations were also similar among treatments and did not have a treatment $x$ week interaction; however, BHBA did increase slightly as the study progressed. Plasma cholesterol was affected by treatment $(P<0.01)$, week $(P<0.01)$, and an interaction of treatment $\times$ week $(P=0.02)$ occurred. Results for cholesterol are also presented in Figure 1 to illustrate these interactions. Heifers fed the CON diet had the least plasma concentrations of cholesterol, which remained fairly static in concentration over the duration of the study. Heifers fed the LFDG diet had similar total cholesterol concentrations to the CON-fed 
Table 3. Plasma FA profiles and concentrations from wk 20 of the feeding period for Holstein heifers fed the control $(\mathrm{CON})$, the low-fat diet containing fat-extracted high-protein dried distillers grains (LFDG), and the high-fat diet containing traditional dried distillers grains with solubles (HFDG)

\begin{tabular}{|c|c|c|c|c|c|}
\hline \multirow[b]{2}{*}{ Item $^{1}$} & \multicolumn{3}{|c|}{ Treatment } & \multirow[b]{2}{*}{ SEM } & \multirow{2}{*}{$\frac{P \text {-value }}{\text { Treatment }}$} \\
\hline & $\mathrm{CON}$ & LFDG & HFDG & & \\
\hline \multicolumn{6}{|l|}{$\mathrm{mg} / 100 \mathrm{mg}$ of $\mathrm{FA}$} \\
\hline C4:0 & $3.28^{\mathrm{a}}$ & $2.64^{\mathrm{ab}}$ & $2.20^{\mathrm{b}}$ & 0.215 & $<0.01$ \\
\hline $\mathrm{C} 5: 0$ & $7.85^{\mathrm{a}}$ & $6.53^{\mathrm{ab}}$ & $5.33^{\mathrm{b}}$ & 0.509 & $<0.01$ \\
\hline C6:0 & 0.28 & 0.30 & 0.24 & 0.037 & 0.40 \\
\hline $\mathrm{C} 7: 0$ & $1.22^{\mathrm{a}}$ & $1.09^{\mathrm{ab}}$ & $0.80^{\mathrm{b}}$ & 0.086 & 0.05 \\
\hline C8:0 & $0.31^{\mathrm{a}}$ & $0.24^{\mathrm{ab}}$ & $0.19^{\mathrm{b}}$ & 0.026 & 0.01 \\
\hline C14:0 & 0.86 & 0.59 & 0.57 & 0.154 & 0.33 \\
\hline $\mathrm{C} 14: 1$ & $0.63^{\mathrm{a}}$ & $0.45^{\mathrm{b}}$ & $0.37^{\mathrm{b}}$ & 0.028 & $<0.01$ \\
\hline C16:0 & 9.94 & 9.54 & 9.75 & 0.387 & 0.39 \\
\hline C16:1 & 0.57 & 0.67 & 0.54 & 0.149 & 0.75 \\
\hline C18:0 & 13.35 & 12.94 & 13.03 & 0.504 & 0.78 \\
\hline C18:1 trans-9 & $0.01^{\mathrm{b}}$ & $0.02^{\mathrm{b}}$ & $0.10^{\mathrm{a}}$ & 0.076 & $<0.01$ \\
\hline $\mathrm{C} 18: 1$ trans -10 & 0.57 & 0.78 & 0.92 & 0.182 & 0.38 \\
\hline C18:1 trans-11 & 1.04 & 1.01 & 0.93 & 0.181 & 0.89 \\
\hline $\mathrm{C} 18: 1$ cis- 9 & $7.26^{\mathrm{a}}$ & $4.82^{\mathrm{b}}$ & $4.96^{\mathrm{b}}$ & 0.257 & $<0.01$ \\
\hline $\mathrm{C} 18: 1$ cis-11 & $0.45^{\mathrm{a}}$ & $0.35^{\mathrm{ab}}$ & $0.27^{\mathrm{b}}$ & 0.046 & 0.03 \\
\hline $\mathrm{C} 18: 2$ cis- 9, cis- 12 & $24.65^{\mathrm{b}}$ & $28.07^{\mathrm{ab}}$ & $30.08^{\mathrm{a}}$ & 1.390 & 0.03 \\
\hline $\mathrm{C} 18: 3 \gamma$ & 0.64 & 0.58 & 0.63 & 0.063 & 0.78 \\
\hline $\mathrm{C} 18: 3 \alpha$ & 1.60 & 0.54 & 0.55 & 0.140 & $<0.01$ \\
\hline C20:4 & 15.61 & 15.46 & 15.88 & 0.918 & 0.87 \\
\hline Other $^{2}$ & 10.64 & 13.50 & 13.02 & 2.478 & 0.41 \\
\hline \multicolumn{6}{|l|}{$\mu \mathrm{g} / \mathrm{mL}$ of plasma } \\
\hline C4:0 & 22.02 & 21.45 & 21.75 & 0.32 & 0.35 \\
\hline C5:0 & 53.24 & 53.11 & 52.71 & 1.33 & 0.95 \\
\hline C6:0 & 1.92 & 2.46 & 2.41 & 0.26 & 0.26 \\
\hline C7:0 & 8.24 & 8.21 & 7.97 & 0.31 & 0.76 \\
\hline C8:0 & 2.10 & 1.90 & 1.93 & 0.15 & 0.60 \\
\hline C14:0 & 6.03 & 5.15 & 5.95 & 1.56 & 0.89 \\
\hline C14:1 & 4.40 & 3.78 & 3.82 & 0.29 & 0.21 \\
\hline C16:0 & $70.74^{\mathrm{c}}$ & $81.36^{\mathrm{b}}$ & $99.71^{\mathrm{a}}$ & 6.38 & $<0.01$ \\
\hline $\mathrm{C} 16: 1$ & 4.29 & 6.11 & 5.40 & 1.46 & 0.64 \\
\hline C18:0 & $97.59^{\mathrm{b}}$ & $109.36^{\mathrm{ab}}$ & $131.65^{\mathrm{a}}$ & 9.01 & 0.03 \\
\hline C18:1 trans-9 & $0.19^{\mathrm{b}}$ & $0.14^{\mathrm{b}}$ & $1.01^{\mathrm{a}}$ & 0.18 & $<0.01$ \\
\hline $\mathrm{C} 18: 1$ trans -10 & 3.99 & 7.08 & 9.25 & 1.75 & 0.12 \\
\hline C18:1 trans-11 & 7.73 & 8.53 & 9.56 & 1.73 & 0.74 \\
\hline C18:1 cis-9 & $50.23^{\mathrm{a}}$ & $40.53^{\mathrm{b}}$ & $51.07^{\mathrm{a}}$ & 3.33 & 0.04 \\
\hline C18:1 cis-11 & 3.14 & 2.94 & 2.73 & 0.31 & 0.64 \\
\hline $\mathrm{C} 18: 2$ cis- 9, cis- 12 & $185.87^{\mathrm{b}}$ & $237.69^{\mathrm{ab}}$ & $300.59^{\mathrm{a}}$ & 23.85 & $<0.01$ \\
\hline $\mathrm{C} 18: 3 \gamma$ & 4.70 & 4.80 & 6.23 & 0.66 & 0.17 \\
\hline $\mathrm{C} 18: 3 \alpha$ & $11.17^{\mathrm{a}}$ & $4.33^{\mathrm{b}}$ & $5.71^{\mathrm{b}}$ & 1.00 & $<0.01$ \\
\hline C20:4 & $110.47^{\mathrm{b}}$ & $129.80^{\mathrm{b}}$ & $160.33^{\mathrm{a}}$ & 9.42 & $<0.01$ \\
\hline Other $^{2}$ & 90.83 & 114.30 & 136.29 & 28.41 & 0.24 \\
\hline Total & $723.8^{\mathrm{a}}$ & $845.4^{\mathrm{ab}}$ & $1010.8^{\mathrm{a}}$ & 67.26 & 0.02 \\
\hline
\end{tabular}

${ }^{1}$ Represented as number of carbons: number of double bonds.

${ }^{2}$ Sum of C9:0, C10:0, C12:0, C13:0, C13:1,C15:0; C17:0; C17:1; C20:0, C20:2, C20:3, C22:1, C22:2, C22:3, C22:4, C22:5, C22:6; C23:0, C24:0, and unidentified FA.

heifers until wk 20, when the cholesterol concentration began to increase. Heifers fed the HFDG diet increased in concentrations of cholesterol by wk 4 of the study, although it was not statistically different from the 2 other treatments until wk 8. By the end of the study, heifers fed the HFDG diet were averaging $100.5 \mathrm{mg} /$ $\mathrm{dL}$ of total plasma cholesterol, whereas the heifers fed the CON and LFDG diets averaged approximately 70 $\mathrm{mg} / \mathrm{dL}$ of cholesterol. Plasma urea $\mathrm{N}$ was the least in the heifers fed the LFDG diet compared with heifers fed the other 2 diets, which had similar concentrations.
The PUN concentrations increased over the duration of the feeding period in all heifers; however, all concentrations were numerically close.

Plasma concentrations of insulin, IGF-1, and leptin are presented in Table 4, and leptin concentrations over the feeding period are also presented in Figure 2. All 3 hormones were similar among treatments, with no significant treatment by week interactions. Insulin and IGF-1 were greater in the initial samples, in agreement with glucose, because the ration being fed before the experimental treatments began had greater starch con- 
Table 4. Plasma metabolites and metabolic hormone concentrations for Holstein heifers fed the control (CON), the low-fat diet containing fatextracted high-protein dried distillers grains (LFDG), and the high-fat diet containing traditional dried distillers grains with solubles (HFDG)

\begin{tabular}{|c|c|c|c|c|c|c|c|}
\hline \multirow[b]{2}{*}{ Item } & \multicolumn{3}{|c|}{ Treatment } & \multirow[b]{2}{*}{ SEM } & \multicolumn{3}{|c|}{$P$-value } \\
\hline & $\mathrm{CON}$ & LFDG & HFDG & & Treatment & Week & Treatment $\times$ week \\
\hline Glucose,${ }^{1} \mathrm{mg} / \mathrm{dL}$ & $74.05^{\mathrm{a}}$ & $72.87^{\mathrm{ab}}$ & $71.53^{\mathrm{b}}$ & 0.981 & 0.06 & 0.01 & 0.35 \\
\hline NEFA, $\mu M$ & 278.5 & 285.4 & 292.9 & 9.81 & 0.63 & 0.67 & 0.90 \\
\hline $\mathrm{BHBA}, \mathrm{mg} / \mathrm{dL}$ & 9.26 & 8.60 & 8.89 & 0.344 & 0.11 & 0.04 & 0.54 \\
\hline Cholesterol, mg/dL & 60.78 & 65.93 & 91.54 & 2.337 & $<0.01$ & $<0.01$ & 0.02 \\
\hline Plasma urea $\mathrm{N}, \mathrm{mg} / \mathrm{dL}$ & $12.40^{\mathrm{a}}$ & $11.33^{\mathrm{b}}$ & $12.23^{\mathrm{a}}$ & 0.405 & 0.03 & 0.01 & 0.46 \\
\hline Leptin, $\mathrm{ng} / \mathrm{mL}$ & 4.07 & 4.08 & 3.90 & 0.187 & 0.44 & $<0.01$ & 0.90 \\
\hline
\end{tabular}

${ }^{1}$ Glucose was measured from serum samples instead of plasma.

tent. Starting from wk 4, after the experiment period began, the plasma concentration of all 3 metabolic hormones increased $(P<0.05)$ over the duration of the study. Plasma leptin concentrations are presented in Figure 2. As it is an indicator of long-term energy status, we thought it was important to show how concentrations were similar among treatments over the course of the feeding period.

\section{Puberty}

Results of progesterone analysis for determination of heifer reproductive status are presented in Table 5 and Figure 3. Not all heifers were cyclic by $300 \mathrm{~kg}$ of

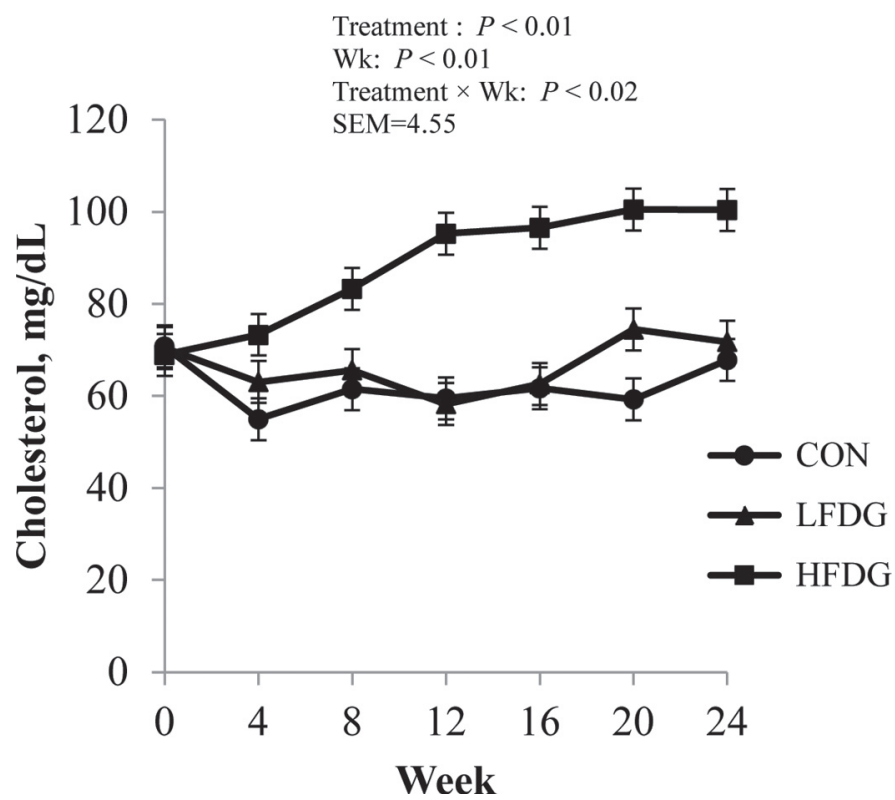

Figure 1. Cholesterol concentrations for Holstein heifers fed the control (CON), a diet containing low-fat dried distillers grains with solubles (LFDG), and a higher-fat diet containing traditional dried distillers grains with solubles (HFDG) over 24 wk. $\mathrm{SEM}=4.55$.
BW or by the end of the study. In turn, for the heifers fed HFDG, $81 \%$ of heifers were cycling before $300 \mathrm{~kg}$, despite being close in age to heifer fed CON and LFDG which only had 36 and $27 \%$ cycling, respectively. Heifers fed the different treatment diets were close in age at $300 \mathrm{~kg}$, which is supported by the similar growth rates demonstrated for these heifers (Anderson et al., 2015). Figure 3 demonstrates in greater detail that more heifers tended to begin cycling at less days of age when fed the HFDG compared with CON $(P=0.08)$. No overall significant effect of treatment was seen when comparing HFDG versus LFDG $(P=0.12)$ or LFDG versus CON $(P=0.82)$.

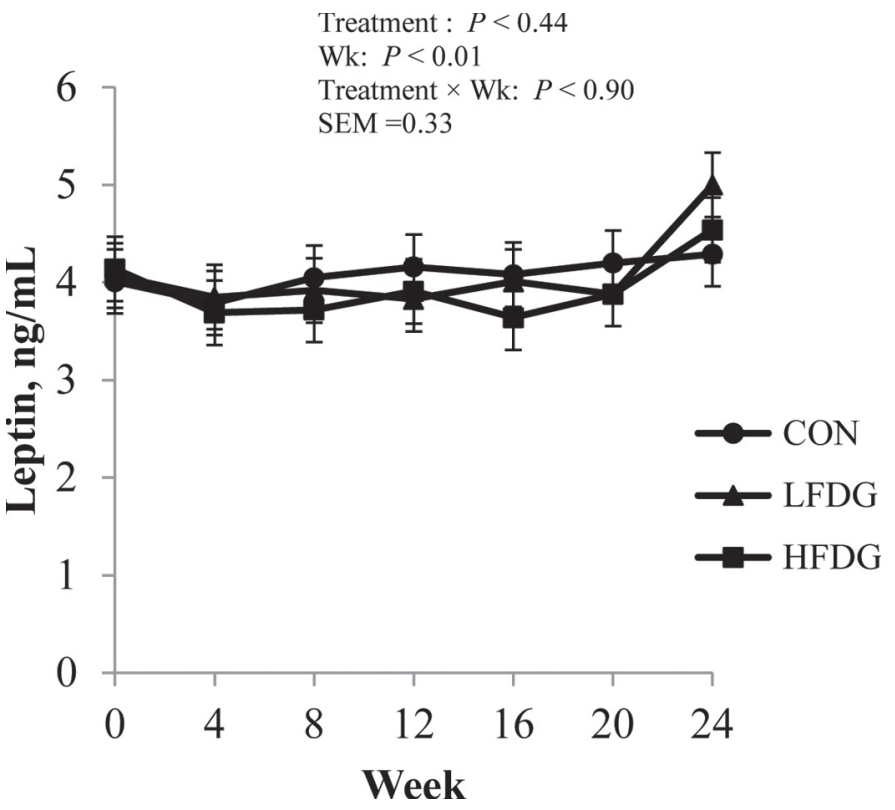

Figure 2. Leptin concentrations for Holstein heifers fed the control $(\mathrm{CON})$, a diet containing low-fat dried distillers grains with solubles (LFDG), and a higher-fat diet containing traditional dried distillers grains with solubles (HFDG) over 24 wk. SEM $=0.33$. 
Table 5. Qualitative data (binomial analysis) related to onset of puberty based on plasma progesterone $(>1$ $\mathrm{ng} / \mathrm{mL}$ ) for heifers fed the control $(\mathrm{CON})$, the diet containing low-fat dried distillers grains (LFDG), and the high-fat diet containing traditional dried distillers grains with solubles (HFDG)

\begin{tabular}{lrrrc}
\hline & \multicolumn{3}{c}{ Treatment } & \multirow{2}{*}{$P$-value } \\
\cline { 2 - 4 } Item & CON & LFDG & HFDG & 0.19 \\
\hline Heifers cycling at $<260$ d of age, $\%$ & 18.2 & 30.0 & 45.5 & 0.03 \\
Heifers cycling at $\leq 300 \mathrm{~kg}$ of BW, $\%$ & 36.4 & 27.3 & 81.8 & \\
Average age at $300 \mathrm{~kg}$ of BW & 279.2 & 283.8 & 286.5 & - \\
\hline
\end{tabular}

\section{DISCUSSION}

Based on the differences in dietary FA, more pronounced differences were expected in plasma total FA concentrations. Thibault et al. (2003) was able to produce a 3 -fold difference in plasma C18:2 by feeding a high oil diet to prepubertal heifers. However, the diet from their study did have greater lipid supplementation with $20 \%$ of soybean oil in the concentrate pellet and ad libitum access to hay compared with the fat content of HFDG diet in the present study. Additional heifers were fed at a younger age $(0-6 \mathrm{mo})$ compared with the present study. Heifers fed the HFDG diet had increased plasma total FA concentrations and increased concentration of $\mathrm{C} 18: 2(\mathrm{~g} / 100 \mathrm{~g}$ of $\mathrm{FA})$ compared with the heifers fed the lower fat $\mathrm{CON}$ and similar concentrations to LFDG diets. This finding partially agreed with our hypothesis, that increased dietary fat from DDGS would alter plasma FA concentrations compared with the CON diet. Biohydrogenation and liver metabolism could be factors in why smaller differences were noted among treatments for blood FA composition compared with what would be expected based on dietary FA compositions. Linoleic acid (C18:2) is a precursor for arachidonic acid (C20:4), which is then used to synthesized prostaglandins (Funston, 2004); these were not

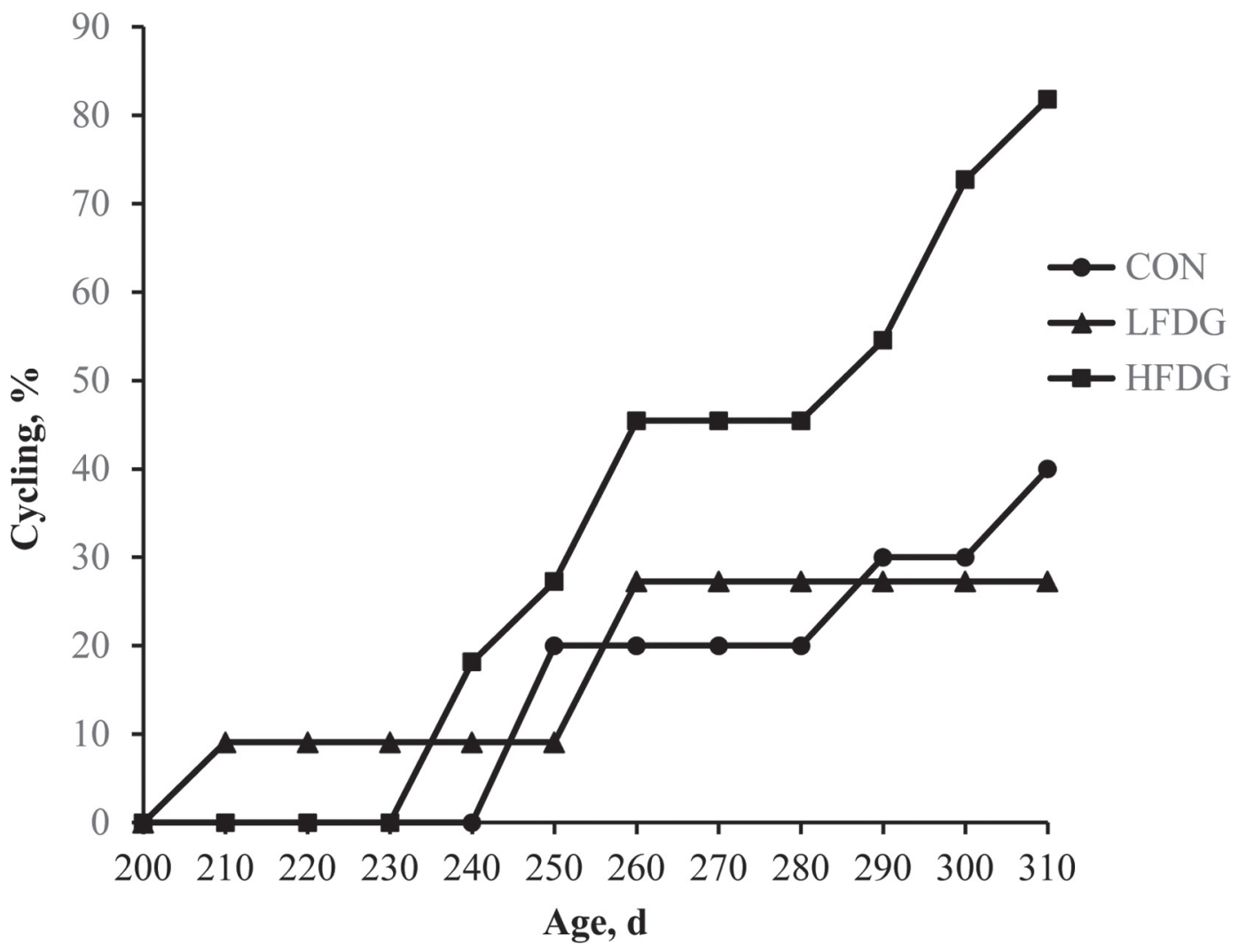

Figure 3. Percent of heifers cycling (pubertal) per treatment by days of age for Holstein heifers fed the control (CON), a diet containing low-fat dried distillers grains with solubles (LFDG), and a higher-fat diet containing traditional dried distillers grains with solubles (HFDG) over $24 \mathrm{wk}(\mathrm{SE}=0.11)$. 
measured in the present study but may have played a role in onset of puberty. Arachidonic acid was greatest in total amount in plasma in the HFDG-fed heifers. All heifers were fed on a high plane of nutrition, as indicated by the high ADG of $0.96 \mathrm{~kg} / \mathrm{d}$; therefore, circulating plasma concentrations may have been elevated in all 3 treatments compared with heifers fed on lower planes of nutrition.

Results from the metabolites and metabolic hormones were surprising. Unlike previous studies (Thomas et al., 1997; Garcia et al., 2003), differences in IGF-1 or insulin were not found among treatments with different fat concentrations. The similar plasma concentrations of IGF-1 and insulin indicate that, in the short term, heifers were at similar energy and metabolic status among treatments (Hall et al., 1995). The conclusion that heifers were at similar metabolic status is further supported by the fact the BHBA and NEFA were not different among treatments. Long-term energy status was also maintained across treatment diets, as indicated by similar plasma leptin concentrations among treatments (Zieba et al., 2005). These results agree with previous research in beef (Garcia et al., 2003) and dairy heifers (Block et al., 2003) that also did not find increased blood leptin concentrations from increased dietary fat. For plasma leptin, even though there was significant week effect on leptin, the increase over time was numerically small and change was gradual, as demonstrated in Figure 2. Other research has also found that leptin increases over time in growing dairy heifers (Block et al., 2003; Chelikani et al., 2009). Metabolite and hormone results, when supported by growth data presented in Anderson et al. (2015), demonstrate that the fat from DDGS performs as well as starch from corn as a dietary energy source for growing heifers. It should be noted that the lack of differences in energy metabolites and hormones among treatments may also be attributed to that fact, as all heifers were being fed at a relatively high plan of nutrition.

The most predominant difference in metabolic profile among treatments was cholesterol. Increased plasma cholesterol with increased dietary fat has been demonstrated by several other researchers (Talavera et al., 1985; Thomas et al., 1997; Funston, 2004). Cholesterol appeared to accumulate in the blood stream and then level off by the end of the trial (Figure 1). It was not until wk 8 of feeding that plasma concentrations were notably different in the HDFG-fed heifers compared with other treatments. This indicates that it may take heifers several weeks to respond to differences in dietary fat content at levels provided in our study. Also, results show that, depending on the amount of dietary fat provided, plasma cholesterol will reach a finite concentration and not continue to increase in dairy heif- ers with prolonged feeding. In relation to reproductive development, cholesterol is an important metabolite because it is a precursor for steroid hormone synthesis. In particular, progesterone may be more affected by cholesterol concentration than estradiol because fewer enzymes and synthesis steps are required to produce progesterone from cholesterol compared with estradiol (Talavera et al., 1985). It was beyond the scope of our study to sample blood at the frequency necessary to determine estradiol and progesterone concentration throughout an estrous cycle. However, we do speculate that differences in age at puberty were most likely a result of increased arachidonic acid, cholesterol, and subsequent steroid hormone synthesis.

In hindsight, progesterone samples for puberty should have been taken over a longer duration or continued to be taken until heifers reached a heavier BW. However, because data of this sort is limited, particularly in regard to the effects of specifically feeding distillers grains to dairy heifers, we felt it was still of value to report our findings despite small number of observations. The average age for Holstein heifers to begin estrous cycles is between 9 to 11 mo (Hoffman, 1997; Serjsen et al., 2000). In our study, some heifers were cycling before 8.6 mo of age. Others (Zanton and Heinrichs, 2007; Chelikani et al., 2009) have reported BW close to 300 $\mathrm{kg}$ for onset of puberty for Holstein heifers. Therefore, heifers that were under this BW could also be considered to have entered precocious or early puberty. When assessed by age or weight, more heifers fed the HFDG diet were cycling early compared with heifers fed the LFDG and CON diets by the end of the sampling period. Onset of puberty is also thought to be related to body fat content (Zieba et al., 2004; Perry, 2012). In the current study, leptin concentrations, which are an indicator of body fat deposition, were similar among treatments. Circulating amount of lipids, including cholesterol and plasma FA, were greater in the HFDGfed heifers compared with LFDG- and CON-fed heifers. This indicates that circulating lipid may have been more important than the amount of adipose deposition on puberty. In retrospect, the small number of heifers on our study, all being fed on a high plane of nutrition, prevents strong conclusions regarding the effect of diet on puberty; however, results do indicate that further research is warranted.

\section{CONCLUSIONS}

In agreement with our hypothesis, increasing the dietary fat with DDGS increased the plasma concentrations of FA and cholesterol. Although, based on analysis of metabolites such as glucose, NEFA, BHBA, and metabolic hormones including insulin, IGF-I, and 
leptin, energy status of the heifers appeared to be unaltered, which partially disagrees with our original hypothesis. Energy status was also maintained across treatment by limit-feeding but was high across all treatments, as indicated by the high ADG of $0.96 \mathrm{~kg} / \mathrm{d}$. The increased dietary fat from traditional DDGS, and consequently increased blood FA and cholesterol compared with other treatment diets, did appear to influence onset of puberty. Although, the puberty data presented is recognized to be very limited in scope and should be interpreted with caution. It is speculated that the increase of cholesterol may lead to increases in steroid hormones, such as progesterone, which may influence the reproductive development. Further research is necessary.

\section{ACKNOWLEDGMENTS}

This work was supported in part by the South Dakota Agriculture Experiment Station (Brookings) and USDA-Agricultural Research Service (Washington, DC) Agreement No. 58-5447-7-322, and was a component of NC-1042: Management Systems to Improve the Economic and Environmental Sustainability of Dairy Enterprises. In memoriam, the authors gratefully acknowledge the role that Arnold Hippen had in helping to plan this research. The authors also thank H. Bruns, F. Diaz-Royon, K. Herrick, K. Mjoun, S. Ranathunga (who were graduate students in the South Dakota State University dairy science department at the time of the study), and South Dakota State University Dairy Research and Training Facility farm crew for assistance with the farm trial.

\section{REFERENCES}

Abdelqader, M. M., A. R. Hippen, K. F. Kalscheur, D. J. Schingoethe, K. Karges, and M. L. Gibson. 2009. Evaluation of corn germ from ethanol production as an alternative fat source in dairy cow diets. J. Dairy Sci. 92:1023-1037.

Allain, C. C., L. S. Poon, C. S. Chan, W. Richmond, and P. C. Fu. 1974. Enzymatic determination of total serum cholesterol. Clin. Chem. 20:470-475.

Ambrose, D. J., J. P. Kastelic, R. Corbette, P. A. Pitney, H. V. Petit, J. A. Small, and P. Zalkovic. 2006. Lower pregnancy losses in lactating dairy cows fed a diet enriched in $\alpha$-linolenic acid. J. Dairy Sci. 89:3066-3074.

Anderson, J. L., K. F. Kalscheur, A. D. Garcia, and D. J. Schingoethe. 2015. Feeding fat from distillers dried grains with solubles to dairy heifers: I. Effects on growth performance and total tract digestibility of nutrients. J. Dairy Sci. 98:5699-5708. http://dx.doi. org/10.3168/jds.2014-9162.

Anderson, J. L., K. F. Kalscheur, A. D. Garcia, D. J. Schingoethe, and A. R. Hippen. 2009. Ensiling characteristics of wet distillers grains mixed with soybean hulls and evaluation of the feeding value for growing Holstein heifers. J. Anim. Sci. 87:2113-2123.

Anderson, J. L., D. J. Schingoethe, K. F. Kalscheur, and A. R. Hippen. 2006. Evaluation of dried and wet distillers grains included at two concentrations in the diets of lactating dairy cows. J. Dairy Sci. 89:3133-3142.
Bligh, E. G., and W. J. Dyer. 1959. A rapid method for total extraction and purification. Can. J. Biochem. Physiol. 37:911-917.

Block, S. S., J. M. Smith, R. A. Ehrhardt, M. C. Diaz, R. P. Rhoads, M. E. Van Amburgh, and Y. R. Boisclair. 2003. Nutritional and developmental regulation of plasma leptin in dairy cattle. J. Dairy Sci. 86:3206-3214.

Chelikani, P. K., D. J. Ambrose, D. H. Keisler, and J. J. Kennelly. 2009. Effects of dietary energy and protein density on plasma concentrations of leptin and metabolic hormones in dairy heifers. J. Dairy Sci. 92:1430-1441.

Daughaday, W. H., I. K. Mariz, and S. L. Blethen. 1980. Inhibition of access of bound somatomedin to membrane receptor and immunobinding sites: A comparison of radioreceptor and radioimmunoassay of somatomedin in native and acid-ethanol-extracted serum. J. Clin. Endocrinol. Metab. 51:781-788.

Delavaud, C., F. Bocquier, R. Baumont, E. Chaillou, T. Ban-Tokuda, and Y. Chillard. 2007. Body fat content and feeding level interact strongly in the short- and medium-term regulation of plasma leptin during underfeeding and re-feeding in adult sheep. Br. J. Nutr. 98:106-115.

Echternkamp, S. E., L. J. Spicer, K. E. Gregory, S. F. Canning, and J. M. Hammond. 1990. Concentrations of insulin-like growth factor-I in blood and ovarian follicular fluid of cattle selected for twins. Biol. Reprod. 43:8-14.

Engel, C. L., H. H. Patterson, and G. A. Perry. 2008. Effect of dried corn distillers grains plus soluble compared with soybean hulls, in late gestation heifer diets, on animal and reproductive performance. J. Anim. Sci. 86:1697-1708.

Funston, R. N. 2004. Fat supplementation and reproduction in beef females. J. Anim. Sci. 82(E. Suppl.):E154-E161.

Funston, R. N., J. L. Martin, D. M. Larson, and A. J. Roberts. 2012. Physiology and endocrinology symposium: Nutritional aspects of developing replacement heifers. J. Anim. Sci. 90:1166-1171.

Funston, R. N., G. E. Moss, and A. J. Roberts. 1995. Insulin-like growth factor-I (IGF-I) and IGF-binding proteins in bovine sera and pituitaries at different stages of the estrous cycle. Endocrinology 136:62-68.

Garcia, M. R., M. Amstalden, C. D. Morrison, D. H. Keisler, and G. L. Williams. 2003. Age at puberty, total fat and conjugated linoleic acid content of carcass, and circulating metabolic hormones in beef heifers fed a diet high in linoleic acid beginning at four months of age. J. Anim. Sci. 81:261-268.

Hall, J. B., R. B. Staigmiller, R. A. Bellows, R. E. Short, W. M. Moseley, and S. E. Bellows. 1995. Body composition and metabolic profiles associated with puberty in beef heifers. J. Anim. Sci. 73:3409-3420.

Hill, T. M., H. G. Bateman II, J. M. Aldrich, and R. L. Schlotterbeck. 2009. Effects of changing the essential and functional fatty acid intake of dairy calves. J. Dairy Sci. 92:670-676.

Hoffman, P. C. 1997. Optimum body size of Holstein replacement heifers. J. Anim. Sci. 75:836-845.

Johnson, M. M., and J. P. Peters. 1993. Technical note: An improved method to quantify nonesterified fatty acids in bovine plasma. J. Anim. Sci. 71:753-756.

Leonardi, C., S. Bertics, and L. E. Armentano. 2005. Effect of increasing oil from distillers grains or corn oil on lactation performance. J. Dairy Sci. 88:2820-2827.

Littell, R. C., G. A. Milliken, W. W. Stroup, R. D. Wolfinger, and O. Schabenberger. 2008. SAS for Mixed Models, 2nd ed. SAS Institute, Cary, NC.

Maciel, M. N., D. A. Zieba, M. Amstalden, D. H. Keisler, J. P. Neves, and G. L. Williams. 2004. Chronic administration of recombinant ovine leptin in growing beef heifers: Effects on secretion of LH, metabolic hormones, and timing of puberty. J. Anim. Sci. 82:2930-2936.

Martin, J. L., A. S. Cupp, R. J. Rasby, Z. C. Hall, and R. N. Funston. 2007. Utilization of dried distillers grains for developing beef heifers. J. Anim. Sci. 85:2298-2303.

McFadden, T. B., T. E. Daniel, and R. M. Akers. 1990. Effects of plane of nutrition, growth hormone, and unsaturated fat on mammary growth in prepubertal lambs. J. Anim. Sci. 68:3171-3179. 
NRC. 2001. Nutrient Requirements of Dairy Cattle. 7th rev. ed. Natl. Acad. Press, Washington, DC.

Perry, G. A. 2012. Harnessing basic knowledge of factors controlling puberty to improve synchronization of estrus and fertility in heifers. J. Anim. Sci. 90:1172-1182.

Schingoethe, D. J., K. F. Kalscheur, A. R. Hippen, and A. D. Garcia. 2009. Invited review: The use of distillers products in dairy cattle diets. J. Dairy Sci. 92:5802-5813.

Schroer, R. C., T. D. Nennich, T. S. Dennis, M. M. Schutz, S. S. Donkin, and D. Little. 2014. Intake and growth of prepubertal dairy heifers fed reduced-fat dried distillers grains. Prof. Anim. Sci. 30:93-98.

Sejrsen, K., S. Purue, M. Vestergaard, and J. Foldager. 2000. High body weight gain and reduced bovine mammary growth: Physiological basis and implications for milk yield potential. Domest. Anim. Endocrinol. 19:93-104.

Simopoulos, A. P. 1991. Omega-3 fatty acids in health and disease and in growth and development. Am. J. Clin. Nutr. 54:438-463.

Sukhija, P. S., and D. L. Palmquist. 1988. A rapid method for determination of total fatty acid content and composition of feedstuffs and feces. J. Agric. Food Chem. 36:1202-1206.

Talavera, F., C. S. Park, and G. L. Williams. 1985. Relationships among dietary lipid intake, serum cholesterol and ovarian function in Holstein heifers. J. Anim. Sci. 60:1045-1051.

Thibault, C., D. Petitclerc, R. Spratt, M. Leonard, K. Sejrsen, and P. Lacasse. 2003. Effect of feeding prepubertal heifers with a high oil diet on mammary development and milk production. J. Dairy Sci. 86:2320-2326.
Thomas, M. G., B. Bao, and G. L. Williams. 1997. Dietary fats varying in their fatty acid composition differentially influence follicular growth in cows fed isoenergetic diets. J. Anim. Sci. 75:2512-2519.

Trinder, P. 1969. Determination of glucose in blood using glucose oxidase with an alternative oxygen acceptor. Ann. Clin. Biochem. $6: 24-27$.

Tucker, H. A. 1981. Physiological control of mammary growth, lactogenesis, and lactation. J. Dairy Sci. 64:1403-1421.

Van Amburgh, M. E., D. M. Galton, D. E. Bauman, R. W. Everett, D. G. Fox, L. E. Chase, and H. N. Erb. 1998. Effects of three prepubertal body growth rates on performance of Holstein heifers during first lactation. J. Dairy Sci. 81:527-538.

Williamson, D. H., J. Mellanby, and H. A. Krebs. 1962. Enzymatic determination of $\mathrm{D}(-)$ - $\beta$-hydroxybutyric acid and acetoacetic acid in blood. Biochem. J. 82:90-96.

Zanton, G. I., and A. J. Heinrichs. 2005. Meta-analysis to assess effect of prepubertal average daily gain of Holstein heifers on firstlactation production. J. Dairy Sci. 88:3860-3867.

Zanton, G. I., and A. J. Heinrichs. 2007. The effects of controlled feeding of a high-forage or high-concentrate ration on heifer growth and first-lactation milk production. J. Dairy Sci. 90:3388-3396.

Zieba, D. A., M. Amstalden, S. Morton, M. N. Maciel, D. H. Keisler, and G. L. Williams. 2004. Regulatory roles of leptin at the hypothalamic-hypophyseal axis before and after sexual maturation in cattle. Biol. Reprod. 71:804-812.

Zieba, D. A., M. Amstalden, and G. L. Williams. 2005. Regulatory roles of leptin in reproduction and metabolism: A comparative review. Domest. Anim. Endocrinol. 29:166-185. 